\title{
MASA DEPAN POLITIK ISLAM
}

\author{
Zainuddin Syarif
}

Dosen Sekolah Tinggi Agama Islam Negeri (STAIN) Pamekasan Madura

\section{ABSTRACT}

Integration between Islam and politics can not be denied, because Islam essentially is a perfect beliefs and teachings that not only teach about worship alone, but also it set all aspects of human life; politics, economics, and social. Islam deal with religion and the world, because Islam is ad-dien wa ad-daulah that regulates worship and muamalah. That is the essence of political leadership as "hirasah al-dinwa siyāsah al-dunyä".

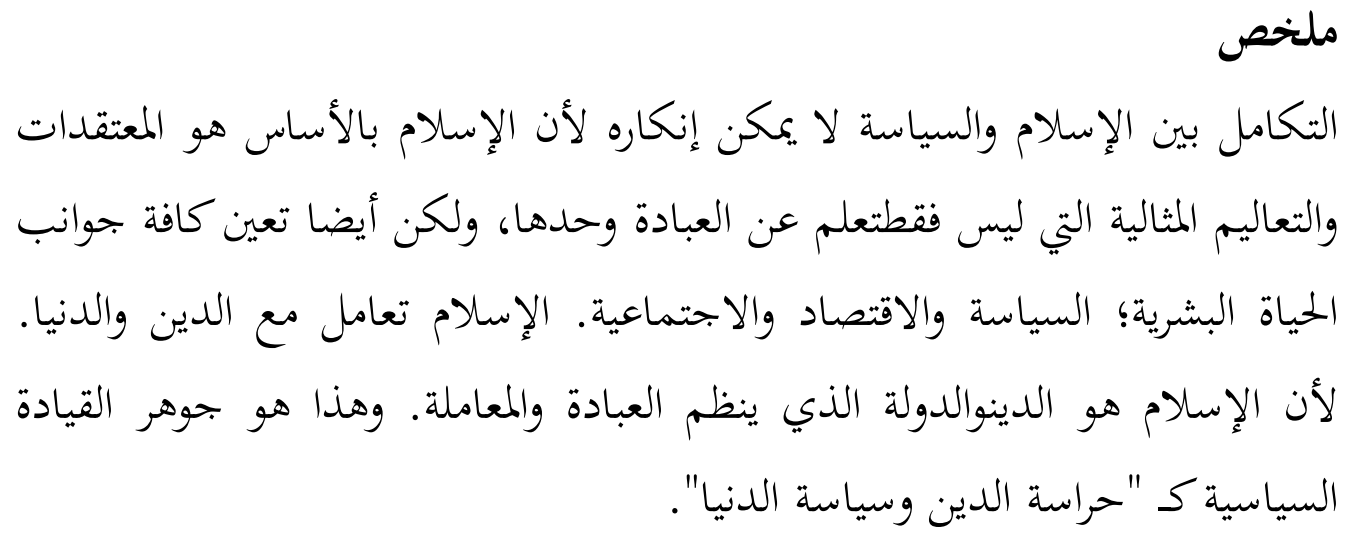

Key word: politik Islam, masa depan, partai Islam, khilafah, imamah.

\section{A. Pendahuluan}

Politik Islam ialah aktifitas politik sebagian umat Islam yang menjadikan Islam sebagai acuan nilai dan basis solidaritas berkelompok. Pendukung perpolitikan ini belum tentu seluruh umat Islam (baca: pemeluk agama Islam). Karena, mereka dalam kategori politik dapat disebut sebagai kelompok politik Islam, juga menekankan simbolisme keagamaan dalam berpolitik, seperti menggunakan perlambang Islam, dan istilah-istilah keislaman dalam peraturan dasar organisasi, khittah perjuangan, serta wacana politik. 
Politik Islam secara substansial merupakan penghadapan Islam dengan kekuasan dan negara yang melahirkan sikap dan perilaku (political behavior) serta budaya politik (political culture) yang berorientasi pada nilai-nilai Islam. Sikap perilaku serta budaya politik yang memakai kata sifat Islam, menurut Dr. Taufik Abdullah, bermula dari suatu keprihatinan moral dan doktrinal terhadap keutuhan komunitas spiritual Islam. ${ }^{1}$

Dalam kontek indonesia, Implikasinya sangat terlihat yaitu partai politik Islam seringkali mengalami problem yang berasal dari dikotomi santri abangan di kalangan umat Islam (dikotomi ini adalah konsekuensi logis dari proses islamisasi yang tidak merata di berbagai daerah nusantara serta perbedaan corak tantangan kultural yang dihadapi). Politik Islam juga menghadapi problema yang berkembang dari adanya kemajemukan di kalangan kelompok Islam itu sendiri. Adalah suatu kenyataan yang tidak dapat dipungkiri bahwa kelompok politik Islam bukanlah merupakan suatu kelompok kepentingan tunggal. Hal ini ditandai oleh banyaknya partai-partai yang bermunculan di kalangan kelompok Islam, baik yang berdasarkan diri pada idiologi dan simbol keislaman maupun yang berbasis dukungan umat Islam.

Politik Islam (partai Islam) di masa awal memiliki tingkat elektabilitas yang tinggi. Bahkan Syahrir pernah secara terang-terangan mengatakan saat desakan untuk segera dilakukan pemilu setelah Agresi Militer Belanda II berhasil dikalahkan bahwa jika pemilu dilaksanakan saat itu maka yang menang adalah partai Islam. Ketika itu politik Islam diwakiliki oleh Partai Masyumi dan kemudian menjadi dua: Partai Masyumi mewakili kelompok modernis dan Partai NU mewakili kelompok tradisonalis. Pada masa Orde Lama, Partai Islam mengalami periferalisasi secara berangsur-angsur sampai dibubarkan oleh Soekarno dan memenjarakan salah satu tokoh politik Islam kharismatik M. Natsir.

Terlepas dari itu semua, dilema politik Islam sering kali berpangkal pada masih adanya problem mendasar dalam kehidupan politik umat Islam. Problema tersebut ada yang bersifat teologis, seperti menyangkut hubungan agama dan politik dalam Islam. Tetapi, ada yang bersifat murni politik, yaitu menyangkut strategi perjuangan politik itu sendiri dalam latar kehidupan poli-

1 Ibn Mandhur, Lisān al Arab, Vol, 6 (Bairut: Dār Ihya al Turath al Araby, 1999), hal. 429 . 
tik Indonesia yang kompleks dengan kelompok-kelompok kepentingan politik majemuk.

Integritas Islam dan politik seperti dalam pemahaman Al-Mawardi (menjaga agama dan mengatur urusan dunia) merupakan pengejawantahan dari dwi fungsi manusia sebagai abd dan khalifah Allah di muka bumi. Manusia sebagai abd mempunyai tanggung jawab dan pengabdian untuk menjalankan syariat atau ibadah yang telah diwajibkan oleh Allah, seperti salat, puasa, zakat, dan haji yang seringkali memerlukan pengaturan dan tegaknya syariat itu melalui kebijakan politik. $^{2}$

Hubungan Islam dan negara betul-betul organik dimana negara berdasarkan syariat Islam dengan ulama sebagai penasehat resmi eksekutif atau bahkan pemegang kekuasaan tertinggi. Sebagai agama sempurna, bagi pemikir politik Islam tipologi ini, Islam bukanlah sekadar agama dalam pengertian Barat yang sekuler, tetapi Agama punya hubungan sangat erat dengan politik. Islam merupakan totalitas sistem yang aplikatif untuk seluruh waktu dan tempat. Pemisahan agama (ad-dien) dan negara (ad-daulah) tidak dapat diterima. Hukum adalah bagian yang melekat dalam Islam. Al-Qur'an memberikan aturan (hukum), sedangkan negara memperkuat pemberlakuan hukum tersebut. ${ }^{3}$

Dalam pemaknaan terhadap Islam sebagai rangkaian dari "agama-kekuasaan-hukum" tidak mungkin syariat Islam ditegakkan tanpa adanya pemerintahan, atau paling tidak orang-orang yang duduk dalam legislatif sebagai perwakilan dari partai Islam mampu memperjuangkan aspirasi umat Islam yang berobsesi menerapkan syariat Islam. Hal ini senada dengan apa yang disampaikan Tabrani bahwa politik adalah bagian integral yang ditargetkan untuk membangun kesinambungan peradaban Islam. Realisasinya, tentu harus ada kekuatan dan kekuasaan yang mendukungnya. ${ }^{4}$

Adanya pemisahan agama dan politik, karena agama itu bersifat ilāhiah, berasal dari wahyu, sakral dan suci. Sedangkan politik merupakan urusan ma-

2 Khalid Ahmad al Shantut," al Tarbiyah as Siyāsah fi al Mujtama' al Muslim, (Beirut: Dār al Bayāriq, 2000), hal. 10.

3 Sukron Kamil, Peta Pemikiran Politik Islam Modern dan Kontemporer, Jurnal Universitas Paramadina, Vol.3 No.1 (September 2003), hal. 63-76

4 R. Hrair Dekmejian, "Islamic Revival Catalysts, Categories, and Consequences", dalam The Politic of Islamic Revivalism, Diversity and Unity, ed Shirren T. Hunter (Washington, D.C: Indiana University Press, 1988), hal. 3-18. 
nusia yang berorientasi pada kekuasaan yang bersifat profan dan kadangkala melibatkan trik-trik dan manipulasi. Ditinjau dari sasaran dan tujuannya, Weber menyebutkan bahwa pada dasarnya seluruh politik mempunyai oreintasi untuk kepentingan materi. Di sinilah kemudian kelompok sekuler mengklaim perlunya adanya pemisahan antara agama dan politik, demi keberlangsungan kesakralan agama itu sendiri.

\section{B. Tipologi Pemikiran Politik Islam.}

Terdapat beberapa pandangan yang berkembang di kalangan umat Islam terkait dengan Islam dan politik atau hubungan agama dan negara. Sampai saat inipun pergumulan pemikiran tersebut tetap menjadi perbincangan yang menarik, bahkan mewarnai terhadap percaturan dan pergumulan politik yang terjadi, termasuk Indonesia. Ada beberapa tulisan yang menarik yang dapat dijadikan acuan dalam melihat tipologi aliran pemikiran tersebut, diantaranya tulisan Munawir Sjadzali mantan menteri agama pada masa kepemimpinan presiden Soeharto. Merupakan diktat untuk mata kuliah al Figh al Siyāsī (Islam dan Tata Negara). Dan tulisan Sukron Kamil dengan judul Peta Pemikiran Politik Islam Modern dan Kontemporer dalam jurnal Universitas Paramadina. Baik Sjadzali maupun Sukron Kamil menyatakan, pada dasarnya ada tiga tipologi pemikiran yaitu; pemikiran politik Islam tradisionalis, Pemikiran Politik Islam sekuler, dan Pemikiran Politik Islam Moderat.

1. Pemikiran Politik Tradisionalis.

Tipologi pemikiran politik Islam tradisionalis ini melihat politik sebagai bagian integral dari agama. Kelompok tipologi pemikiran ini diantaranya: Abu Hasan Ali bin Habib al Mawardi (975-1059), Rasyid Rida (1865-1935), Sayyid Quthub (1906-1966), Abu al 'A'la al Maududi (1903-1979). Al-Mawardi menegaskan bahwa kepemimpinan sebagai bagian dari politik bertujuan untuk menjaga dan melestarikan agama serta mengatur urusan dunia ${ }^{5}$. Ketika berbicara tentang pengaturan urusan dunia sebagimana yang dilontarkan al-Mawardi, maka tanggung jawab pemimpin (pemerintah) dan negara adalah memberikan kenyamanan (kemaslahatan) kepada masyarakat dalam melakukan aktivitas

5 Abī al Hasan 'Alī bin Muhammad bin Habīb al Bahrī al Baghdādī al Māwardī, Al Ahkām al Sulțāniyyah wa al Walāyāt al Diniyyah, (Beirut: Dār al Kutub al 'Ilmiyah, 450 H), hal. 5. 
sehari-hari berdasarkan aturan (tata nilai) agama. Karena esensi tujuan politik itu sendiri berdasarkan beberapa pengertian yang telah dipaparkan di atas, pada dasarnya merupakan pengaturan (pemerintahan) yang memberikan pelayanan kemaslahatan kepada masyarakat yang diperintah.

Integritas Islam dan politik seperti dalam pemahaman Mawardi (menjaga agama dan mengatur urusan dunia) merupakan pengejawantahan dari dwi fungsi manusia sebagai abd dan khalifah Allah di muka bumi. Manusia sebagai abd mempunyai tanggung jawab dan pengabdian untuk menjalankan syariat atau ibadah yang telah diwajibkan oleh Allah, seperti salat, puasa, zakat, dan haji yang seringkali memerlukan pengaturan dan tegaknya syariat itu melalui kebijakan politik. Sebagai khalifah Allah artinya manusia sebagai makhluk sosial tidak lepas dari adanya interaksi satu sama lain, sehingga sangat diperlukan adanya pimpinan dalam mengatur urusan sosial tersebut. Kebutuhan akan pimpinan tersebut tentu saja memerlukan kesepakatan politik.

Dalam pandangan al-Mawardi keterkaitan Islam dan politik tidak dapat ditolak, karena Islam pada hakikatnya merupakan keyakinan dan ajaran yang sempurna, yang tidak hanya mengajarkan tentang ibadah semata, tetapi di dalamnya juga mengatur perihal segala aspek kehidupan manusia; kehidupan berpolitik, perekenomian, dan sosial kemasyarakatan. Islam berhubungan dengan agama dan dunia, karena sesungguhnya Islam adalah ad-dien wa ad-daulah yang mengatur tentang ibadah dan muamalah. ${ }^{6}$ Itulah esensi kepemimpinan politik sebagai "hirasah al-dìn wa siyāsah al-dunyā".

Sayyid Qutub dalam Khalid Ahmad Shantut juga menegaskan keterkaitan agama dan politik, dalam sebuah pernyataannya," tidak mungkin dakwah yang mengajak kebaikan bisa diteggakkan tanpa adanya raja (pemimpin) pemerintahan. Karena pada dasarnya adanya perintah dan larangan tidak bisa direalisasikan tanpa adanya pemimpin"7. Maka dengan demikian perlu adanya pemimpin yang bisa menegakkan kemaslahatan dan mencegah dari kejelekan dan kemaksiatan. Dalam pandangan Quthub, pemimpin merupakan mata rantai yang menghubungkan kedekatan kepada Allah dan hubungan dalam mempererat persaudaran antar sesama. Sehingga dengan kepemimipinan tersebut

6 Lihat, Khalid Ahmad al Shantut," al Tarbiyah as Siyāsah fi al Mujtama' al Muslim, (Beirut: Dār al Bayāriq, 2000), hal. 10.

7 Ibid, hal. 18 
dapat ditegakkan kehidupan masyarakat, seperti masyarakat yang pernah dibangun Nabi di Madinah.

Dalam isitilah Zainuddin Maliki kelompok pemikiran politik ini termasuk tipologi Islam Organik $^{8}$ yang mengakui perlunya penyatuan agama dan politik (kekuasaan). Hubungan Islam dan negara betul-betul organik dimana negara berdasarkan syariat Islam dengan ulama sebagai penasehat resmi eksekutif atau bahkan pemegang kekuasaan tertinggi. Sebagai agama sempurna, bagi pemikir politik Islam tipologi ini, Islam bukanlah sekedar agama dalam pengertian Barat yang sekuler ${ }^{9}$, tetapi Agama punya hubungan sangat erat dengan politik. Islam merupakan totalitas sistem yang aplikatif untuk seluruh waktu dan tempat. Pemisahan agama (ad-dien) dan negara (ad-daulah) tidak dapat diterima. Hukum adalah bagian yang melekat dalam Islam. Al-Qur'an memberikan aturan (hukum), sedangkan negara memperkuat pemberlakuan hukum tersebut. ${ }^{10}$

Dalam pemaknaan terhadap Islam sebagai rangkaian dari “agama-kekuasaan-hukum" tidak mungkin syariat Islam ditegakkan tanpa adanya pemerintahan, atau paling tidak orang-orang yang duduk dalam legislatif sebagai perwakilan dari partai Islam mampu memperjuangkan aspirasi umat Islam yang berobsesi menerapkan syariat Islam. Hal ini senada dengan apa yang disampaikan Tabrani bahwa politik adalah bagian integral yang ditargetkan untuk membangun kesinambungan peradaban Islam. Realisasinya, tentu harus ada kekuatan dan kekuasaan yang mendukungnya ${ }^{11}$, yaitu berupa pemerintahan.

Sjadzali lebih lanjut menjelaskan bahwa sistem ketatanegaraan atau politik Islam yang diidealkan oleh kelompok pemikir politik Islam ini adalah sistem yang telah dilaksanakan pada masa nabi Muhammad dan Khulafā al Rasyidīn ${ }^{12}$. Idealitas ketatanegaraan tersebut diawali oleh rintisan Nabi dalam memba-

8 Zainuddin Maliki, Agama Priyayi Makna Agama di Tangan Elit Penguasa, (Yogyakarta: Pustaka Marwa, 2004), hal. 29.

9 Lihat, Sukron Kamil, Peta Pemikiran Politik Islam Modern dan Kontemporer, Jurnal Universitas Paramadina, Vol.3 No.1 (September 2003), hal. 63-76.

10 R. Hrair Dekmejian, "Islamic Revival Catalysts, Categories, and Consequences", dalam The Politic of Islamic Revivalism, Diversity and Unity, ed Shirren T. Hunter (Washington, D.C: Indiana University Press, 1988), hal. 3-18.

11 Abdul Mukti Tabrani, "Politik Kiai dan Kiai Politik", Jawa Pos, 09 Januari 2004, hal. 4.

12 Munawir Sjadzali, Islam dan Tata Negara; Ajaran, Sejarah dan Pemikiran, (Jakarta: Universitas Indonesia Press, 1993), hal. 1. 
ngun persatuan komunitas Islam yang diikat dengan sebuah perjanjian yang dikenal dengan bai'at aqabah pertama dan dilanjutkan dengan aqabah yang kedua. Puncak rintisan bangunan negara, setelah Nabi melaksanakan hijrah Yastrib, yang kemudian hari dikenal dengan Madinah. Integritas masyarakat tersebut dibagun atas dasar kebutuhan dan kemaslahatan barsama, yang tidak hanya terdiri dari komunitas masyarakat Muslim, tetapi terdiri dari berbagai perbedaan ras, suku, budaya dan agama. Perbedaan-perbedaan tersebut diatur dan diikat oleh Nabi sebagai pimpinan komunitas dengan perjanjian yang dikenal dengan piagam Madinah. Katauhidan yang diajarkan Nabi di Madinah diakui oleh umat Islam sebagai fondasi tatanan politik Islam ${ }^{13}$. Sjadzali menegaskan, banyak pakar yang menyatakan bahwa piagam Madinah sebagai kontitusi atau undang-undang dasar negara Islam. Sebab bila ditelusuri, Madinah sebagai sebuah negara telah memenuhi persyaratan unsur-unsur sebagai negara, seperti dalam rumusan "Konvensi Montevido" (1933), yaitu adanya rakyat, wilayah dan pemerintah ${ }^{14}$.

Rakyat atau masyarakat Madinah terdiri dari beberapa unsur, pertama masyarakat yang mengakui Nabi tidak hanya sebagai pemimpin komunitas, tetapi sebagai rasul pembawa aqidah kebenaran (Islam). Hal ini bisa dilihat pada peristiwa bai'at aqabah pertama dan yang kedua. Kedua, unsur rakyat yang terdiri dari berbagai perbedaan ras, suku, budaya, dan agama atau dengan kata lain masyarakat yang plural. Sebagian dari rakyat ini mengakui Nabi sebagai pimpinan komunitas (negara) atas dasar kepentingan dan kemaslahatan bersama, bukan karena kesatuan dalam keyakinan (aqidah). Realitas ini dapat dilihat dalam bangunan negara Madinah ${ }^{15}$.

Wilayah Madinah, adalahnegara yang merdeka yang terdiri dari masyarakat pendatang (Muhajirin) termasuk juga Nabi sendiri, masyarakat setempat yang sudah mengakui terhadap kerasulan Nabi dan ajaran yang dibawanya (Islam), dan masyarakat setempat yang masih berpegang teguh kepada keyakinan agamanya. Pemerintah dalam negara Madinah, merupakat seperangkat aparatur

13 Bassam Tibi, Islam Kebudayaan dan Perubahan Sosial, (Terj:Misbah Zulfa Ellizabet dan Zainul Abbas), (Yogyakarta: Tiara Wacana, 1999), hal. 55.

14 A.Ubaedillah dan Abdul Rozak, (Penyunting), Demokrasi, Hak Asasi Manusia dan Masyarakat Madani, (Jakarta: ICCE (Indonesian Center for Civic Education, 2006), hal. 20.

15 Lihat, Muhmmmad Imarah, Al-Islām Wa al-Siyāsah al-Radd Ala Shibhatial-Alamaniyyinā, (Mesir: Dār al-Tauzi' wa al-Nashr al-Islāmiyah, 2007), hal. 37. 
yang menjadikan Nabi sebagai pimpinan dengan menetapkan hukum (perjanjian), menjalankan ketertiban, keamananan, dan keamananan berdasarkat kesepakatan perjanjian.

Ketatanegaran yang dibangun Nabi menjadi konsep perjalanan pemerintahan Islam selanjutnya yaitu Khulafā al Rasyidīn, yang pada akhirnya melahirkan konsep imāmah atau khiläfah (pemerintahan). Konsep ini terlahir dari dua kelompok besar dalam pemikiran Islam yaitu Ahl al Sunnah (Sunni) dan Syiah. ${ }^{16}$ Masing-masing kelompok Sunni dan Syiah mempunyai konsep tentang kewajiban kepemimpinan politik dan ketatanegaraan sebagai ciri yang membedakan keduanya. Kewajiban khiläfah menurut kelompok Sunni sebagaimana yang jelasakan al Mawardi merupakan kewajiban berdasarkan syariat melalui proses ahl al hāl wa al 'aqd. Secara harfiah ahl al hāl wa al aqd adalah orang yang mempunyai wewenang untuk menentukan dan memutuskan. Di masa Nabi dan Khulafa al Rasyidin proses penentuan dan keputusan disebut dengan ahl al shurā.

Al-Mawardi menyadari bahwa dalam masyarakat terdapat kelompok yang mempunyai pandangan bahwa kewajiban khiläfah tidak hanya kewajiban berdasarkan syariat tetapi ada kelompok pandangan lain yang menyatakan bahwa kewajiban khiläfah berdasarkan akal. Pandagan ini secara moderat ia ulas dalam bab pertama tentang batasan pengangkatan imämah. Berbeda dengan konsep Sunni, Syiah mempunyai konsep kewajiban imāmah yaitu dalam hal penentuan imam tidak berdasarkan pemilihan, keinginan dan kehendak umat, karena umat tidak mempunyai wewenang dalam pengangkatan dan sekaligus pemberhentiannya. Pengangkatan dan penunjukan Imam berdasarkan ketentuan nas (kehendak Allah) melalui Nabi atau Imam sebelumnya ${ }^{17}$.

\section{Pemikiran Politik Islam Sekuler.}

Tipologi pemikiran politik ini mempunyai pandangan bahwa nabi $\mathrm{Mu}-$ hammad sebagai pembawa risālah agama Islam hanya mengajarkan ketauhidan dan tata cara ibadah kepada Allah semata, tidak pernah mengajarkan tentang

16 Lihat, Abd. Razak Ahmad Sanhuri, Usūl al Hukmi fì al Islām, (Mesir: Mahrajan al Qirā'ah lil Jami', Maktabah al Usrah, 2003), hal. 63.

17 Syek Muhammad Ridha al Musaffar, Akidah Syiah Imāmiyah, (Terj;Muhammad H. Acango), (Jakarta: Abudzarr Press, t.t), hal. 45. 
tata cara kehidupan bermasyarakat dan bernegara. Apalagi tentang kewajiban khilāfah atau imāmah. kelompok ini menempatkan Islam sebagaimana agamaagama lainnya yang menyatakan bahwa agama terpisahkan dengan persoalan politik dan negara.

Pemisahan agama dan politik, karena agama itu bersifat ilāhiah, berasal dari wahyu, sakral dan suci. Sedangkan politik merupakan urusan manusia yang berorientasi pada kekuasaan yang bersifat profan dan kadangkala melibatkan trik-trik dan manipulasi. Ditinjau dari sasaran dan tujuannya, Weber menyebutkan bahwa pada dasarnya seluruh politik mempunyai oreintasi un-

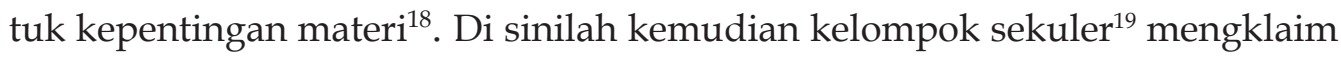
perlunya adanya pemisahan antara agama dan politik, demi keberlangsungan kesakralan agama itu sendiri.

Tokoh yang getol menolak penyatuan agama dan politik adalah Ali Abd al Raziq (1888-1966) melalui karya spektakukernya "al-Islām wa Usūl al-Hukmi", dan Lutfi al Sayyid (1872-1963). Buku karya Raziq ini terbit pada tahun 1925. Menurut Erwin I.J. Rosenthal sebagaimana yang dikutip Antony Balck bahwa buku tersebut, memberikan justifikasi terhadap revolusi Turki yang sedang menjalankan pemerintahan sekuler yaitu pemisahan atoritas agama dan politik $^{20}$. Kerena pada tahun 1924 Mustafa Kemal Ataturk selaku pimpinan Turki pada sasat itu secara resmi membubarkan sistem kekhalifahan ${ }^{21}$. Buku Raziq sekaligus menolak terhadap pandangan Rasyid Rida yang menekankan tegaknya kekhalifahan. Raziq menyatakan bahwa Islam sama sekali tidak berkaitan dengan kekhalifahan.

Embrio pemikiran Raziq bersumber dari dua kelompok besar dalam khasanah pemikiran dalam Islam yaitu Mu'tazilah dan Khawarij. Mereka menyatakan kewajiban tegaknya khiläfah tidak dapat diterima baik secara akal maupun syara'. Kewajiban bagi umat Islam adalah melaksanakan hukum-hukum syariat. Bilamana masyarakat sudah melaksanakan syariat dan berkeadilan, maka

18 Max Weber, "The Sociology of Religion”, (Boston: Beacon Press, 1963), hal. 235.

19 Maliki, Agama Priyayi, hal. 30.

20 Antony Black, Pemikiran Politik Islam Dari Masa Nabi Hingga Masa Kini, (Terj:Abdullah Ali \& Mariana Ariestyawati, (Jakarta: PT Serambi Ilmu Semesta, 2006), hal. 569.

${ }^{21}$ Leonard Binder, Islam Liberal Kritik terhadap Ideologi-Ideologi Pembangunan, (Terj: Imam Muttaqin), (Yogyakarta: Pustaka Pelajar, 2001), hal. 192. 
tidak diperlukan lagi politik yang bertujuan membangun pemerintahan. ${ }^{22}$

Pemikiran Mu'tazilah dan Khawarij yang telah dipaparkan di atas, diperkokoh dengan pandangan Abduh yang menyatakan bahwa dalam Islam tidak ada kekuasaan keagamaan, menjadi rujukan yang mempengaruhi lahirnya pandangan Raziq yang kontroversial, sehingga menuai kritikan dan reaksi keras dari dari beberapa ulama Mesir pada saat itu. Salah satu ulama yang gencar memberikan kritikan adalah Muhammad Rasyid Rida murid Muhammad Abduh. Pada saat itu pula (tahun 1925) ia sedang semangat-semangatnya melakukan sosialisasi tentang perlunya mempertahankan sistem kekhalifahan. Salah satu upaya yang ia lakukan dengan menerbitkan majalah al-Mannar. Kritikan dan reaksi keras Rida seperti yang dijelaskan Sjadzali, memberikan andil terhadap pengutukan dan pengucilan oleh majelis ulama yang berakhir dengan dicopotnya Raziq dari jabatan hakim pada mahkamah syari'ah Mesir ${ }^{23}$.

Penolakan Raziq terhadap kewajiban khiläfah, didasari oleh analisisnya terhadap dalil al Qur'an yang sering dijadikan oleh para ulama sebagai justifikasi kewajiban tegaknya khilāfah. Yaitu firman Allah, "Hai orang-orang yang beriman, taatilah kepada Allah dan taatilah Rasul serta Uli al Amri diantara kalian ${ }^{24}$. Seperti yang dijelaskan Raziq, Rida dan Ibn Hazm al Zahiri, menjadikan ayat ini sebagai justifikasi dalam memperkuat pandangannya tentang kewajiban khiläfah. Ayat ini digunakan juga oleh al Mawardi sebagai sandaran dalam menjustifikasi kewajiban imāmah yang berperan sebagai pengganti nabi melestarikan agama dan politik dunia. Menurut Raziq, uli al amri tidak dapat dijadikan dalil terhadap kewajiban tegaknya khiläfah, karena ia sebagaimana para ulama pada umumnya menafsirkan uli al amri sebagai tokoh atau pemuka umat Islam pada masa rasul ataupun sesudahnya, seperti para khiläfah, qadi, komandan pasukan dan para ulama. Tidak ditemukannya dasar normatif yang menunjukkan kewajiban khilafah secara pasti, maka ia tetap bersikukuh dengan pandangannya bahwa khilafah dalam Islam tidak mempunyai akar referensi baik secara nash maupun akal. Sehingga ia tetap berkesimpulan bahwa risalah nabi bukanlah kerajaan, sepanjang sejarah para

${ }^{22}$ Lihat, Ali Abd. al Raziq, Al Islām wa Usūl al Hukmi: Bahth fĩ al Khilāfah wa al Hukumah fï al Islām,(Mesir: Dār al Hilal, 1925), hal. 47.

23 Munawir Sjadzali, Islam ..., hal. 139.

${ }^{24}$ al Qur'an, 4 (An Nisa' : 59), hal. 186. 
rasul tidak mengenal penggabungan antara risālah dan kerajaan. Pemahaman umat Islam pada umumnya bahwa pada diri nabi adalah raja sekaligus rasul yang telah meletakkan dasar-dasar politik pemerintahan. Padahal hal itu dapat dibantah karena kerajaan mempunyai tumpuan tersendiri begitu juga risālah. ${ }^{25}$

Penolakan Raziq terhadap penyatuan agama dan politik, serta diri nabi sebagai rasul sekaligus pemimpin negara, merupakan penolakan yang dipaksakan. Hal itu dapat dilihat dalam pernyataannya "dalam sejarah para rasul, kita tidak dapat mengenal adanya penggabungan yang dilakukan Allah antara risālah dan kerajaan, kecuali hanya sebagian" ${ }^{26}$ Dari pernyataan ini, berarti ia mengakui bahwa sebetulnya dalam perjalanan risālah rasul ada yang sekaligus sebagai raja atau pemimpin negara. Pertanyaan sebagai sebuah kritikan mengapa ia tidak mengakui bahwa pada diri nabi Muhammad adalah rasul sekaligus pemimpin negara? Padahal sejarah telah membuktikan bahwa Nabi membangun negara Madinah mempunyai otoritas sebagai rasul dan pemimpin negara di sisi lain. Konsep khiläfah yang dikutip oleh Raziq dari beberapa tokoh dalam bab awal hampir tidak ada bantahan. Hanya ia menyampaikan bahwa khiläfah dalam perjalanannya berubah menjadi kerajaan absolut seperti yang terjadi pada masa daulah Umayyah dan Abbasiyyah. Iapun juga menyampaikan bahwa ada yang berpendapat bahwa khalifah memperoleh kekuasaan dari masyarakat, mereka pula yang memilih khalifah dalam jabatan tersebut. AlMawardi juga sependapat bahwa masyarakat bisa memilih khalifah, tetapi ia membatasi pemilihan tersebut dengan model ahl al hāl wa al aqd.

\section{Pemikiran Politik Islam Moderat.}

Berbeda dengan pemikiran politik tradisional dan sekuler, pemikiran politik Islam moderat merupakan benang merah dari kedua pemikiran tersebut. Pokok pemikiran politik ini menyangkal bahwa Islam merupakan agama sempurna yang mengatur dan menentukan urusan politik, sehingga agama dan politik menjadi satu-kesatuan yang tak terpisahkan. Begitu juga menolak bahwa Islam sama sekali tidak berkaitan dengan politik, sehingga politik dan negara tidak perlu direkat agama. Kelompok ini lebih mengedepankan sub-

\footnotetext{
25 Ali Abd al Raziq, Al Islām ..., hal. 88-89.

${ }^{26}$ Ibid, hal. 89.
} 
tansi dari pada simbol, lebih menekankan kepada hakikat dan pelayanan politik daripada nama dan bentuk negara.

Tokoh-tokoh dari kelompok pemikiran politik moderat diwakili oleh tokoh modern dan kontemporer diantaranya; Muhammad Abduh (1862-1905), Muhammad Abid al-Jabiri (1936), Nurcholis Madjid (1939-2005), Azyumardi Azra (1955) dan Masykuri Abdillah (1958) sebagai perwakilan pemikir Indonesia. Pandangan kelompok ini didasari oleh pemahaman bahwa Islam hanya memberikan kode etik bagaimana politik dijalankan berdasarkan prinsip-prinsip yang terkandung di dalamnya. Islam mengajarkan ketauhidan dan menjunjung tinggi nilai-nilai keadilan, persamaan hak dan kewajiban, dan perdamaian, demi kemaslahatan masyarakat seutuhnya. Hal ini diperkuat oleh Muhammad Saltut dalam bukunya" al Islām 'Aqidah wa Shari'ah" bahwa dasar-dasar negara Islam meliputi empat hal yaitu; persaudaraan keagamaan, kesejahteraan sosial masyarakat, Musyawarah (shurā) dan keadilan ${ }^{27}$. Empat dasar negara Islam inilah secara subtansial harus terpenuhi dalam penyelenggaran pemerintahan apapun bentuk dari negara tersebut. dasar-dasar inilah yang menjadikan pijakan kelompok moderat yang berpandangan Islam tidak memberikan aturan pasti bentuk dari suatu negara, tetapi bagaimana negara secara subtansial menjalankan empat dasar prinsip tersebut sebagai ciri dari negara Islam.

Tidak jauh berbeda dengan kelompok modernis yang disebut di atas, pandangan kelompok intelektual Indonesia seperti Nurcholis Madjid, dan Azyumardi Azra. Pandangan Madjid memposisikan hubungan agama dan politik dari segi etis. Artinya bahwa kegiatan politik tidak dibenarkan lepas dari pertimbangan nilai-nilai agama. Oleh karenanya, Imam Syafi' $i^{28}$ mempertegas bahwa politik harus bertalian dengan anjuran syariat. Atas dasar pertimbangan nilai-nilai keagamaan diharapkan adanya perilaku politik bermoral tinggi. Inilah yang dimaksud dengan konsep "agama tidak dapat dipisahkan dari politik" ${ }^{29}$. Senada dengan hal tersebut, pemikiran Azra menawarkan konsep subtatif agama yang dikemas menjadi Islam substantif, yang mengembangkan pesan-pesan moral dan tema-tema sentral seperti keadilan dan egalitarianisme,

27 Muhammad Saltut, Al Islām 'Aqidah wa Shari'ah, (Mesir: Dār al Qalam, 1966), hal. 441.

28 Ibn Qayyim, At țurūq, hal. 13.

29 Nurcholish Madjid, "Islam dan Politik, Suatu Tinjauan atas Prinsip-Prinsip Hukum dan Keadilan”, Jurnal Pemikiran Islam Paramadina, No (Juli, 1998), hal. 48-57. 
dan bukan hanya menonjolkan simbol. Apabila kiai sebagai tokoh agama mau bergerak di bidang politik sebaiknya bukan pada tataran high politics (praktis), tapi cukup sebagai moral pressure ${ }^{30}$ (kekuatan atau moral) kepada seluruh partai politik dan kekuasaan yang ada, bukan kekuatan penekanan yang menentukan (decisive force) dan terlibat secara pragmatis.

Dengan demikian kelompok moderat ini, menempatkan agama sebagai bingkai etis dalam berbagai aspek kehidupan termasuk di dalamnya politik. Bukan agama sebagai format dalam menentukan negara dan sistem pemerintahannya. Esensi ajaran Islam yang dibawa oleh nabi Muhammad adalah mengajak manusia bertauhid kepada Allah yang di dalamnya terkandung ajaran membangun persaudaran, menjunjung tinggi keadilan, persamaan dan egaliter, dan musyawarah. Bila negara mampu memenuhi hal ini dan dapat menjamin kesejahteraan hidup masyarakat, bagi penulis apapun bentuk dari negara tersebut berarti telah memenuhi kriteria sebagai ciri dari negara Islam.

Lebih tegas lagi titik temu yang ditawarkan Abdillah, bahwa perlu adanya sinergisitas antara Islam dan demokrasi. Tawaran ini yang dikenal dengan konsepnya demokrasi religious. Dalam pandangannya demokrasi sebagai sistem nilai tidak cukup dibingkai dalam frame paham sekularisme tapi juga dalam bingkai yang relegious, yang menghormati nilai-nilai agama dan budaya lokal ${ }^{31}$. Lebih lanjut ia menyatakan demokrasi yang religious adalah memberikan "kebebasan dan toleransi, sebagai nilai-nilai dasar demokrasi, disamping persamaan dan keadilan. Oleh sebab itu karena Indonesia bukan negara agama, maka hubungan antara agama dan politik tidak bisa bersifat formal-legal, tetapi yang lebih sesuai adalah hubungan yang bersifat subtantifistik ${ }^{32}$. Ia melihat kesinergisan sistem demokrasi khususnya di Indonesia karena dua hal; ${ }^{33}$ Pertama, nilai-nilai demokrasi sesuai dengan nilai-nilai Islam tentang masyarakat. Kedua, cara yang tepat untuk mengartikulasikan aspirasi dan kepentingan-kepentingan Islam. Karena umat Islam di Indonesia adalah mayoritas, sementara sistem

30 Azyumardi Azra, Islam Substantif Agar Umat Tidak Jadi Buih, (Bandung: Mizan, 2000), hal. 145.

31 Masykuri Abdillah, Menuju Demokrasi Yang Religius, dalam http://www.nu.or.id/ page. php?lang=id\&news_view_id=1253 (20 Februari 2004)

32 Ibid.

33 Masykuri Abdillah, Demokrasi di Persimpangan Makna; Respon Intelektual Muslim Indonesia terhadap Konsep Demokrasi (1966-1993), (Yogyakarta: Tiara Wacana, 1999), hal. 76. 
yang demokratis pada dasarnya adalah sistem kekuasaan mayoritas. Mengacu pada konsep Masykuri Abdillah tersebut, maka keinginan menjalankan nilainilai Islam melalui bangunan sistem kenegaraan yang dianut dalam hal ini demokrasi. Karena demokrasi yang diterapkan di Indonesia telah mengakomodir nilai-nilai dan tujuan agama.

\section{Nasib Politik Islam Idonesia}

Indonesia memiliki sejarah dan tradisi panjang pergerakan sosial, terutama dalam perjuangan kemerdekaan. Bahkan organisasi keagamaan ikut memiliki andil dan peran yang sangat besar, seperti Muhammadiyah (1912) dan Nahdatul Ulama (1926) yang keduanya merupakan pengawal faham Islam moderat dan setia pada Pancasila. Kondisi geografis Indonesia yang terdiri dari belasan ribu pulau dan memiliki keragaman bahasa, budaya dan agama, ikut serta melahirkan dinamika sosial budaya yang pengaruhnya sangat dirasakan masuk ke ranah politik. ${ }^{34}$

Sejak merdeka tahun 1945 sampai sekarang kita masih bingung mencari model, trial and error. Masyarakat Indonesia yang sedemikian majemuk memerlukan waktu yang tidak pendek untuk membangun kohesi berbangsa dan bernegera. Kelahiran "Negara Indonesia" tidak serta-merta melahirkan "Bangsa Indonesia" yang solid, karena "keindonesiaan" kita masih dalam proses menjadi. Kita belum memiliki tradisi yang kuat dan rasional dalam kehidupan bernegara dan berpemerintahan.

Penegakan hukum dan kultur politik sangat mengecewakan sehingga mendevaluasi gerakan reformasi dan demokratisasi. Akibatnya, masyarakat semakin apatis dan kecewa terhadap parpol dan politik. Diduga, sentimen deparpolisasi dan golput semakin meningkat secara signifikan. Sistim politik dan pemerintahan yang dibangun pasca Soeharto, yang dikenal dengan era reformasi, yang lebih menonjol adalah kebebasan berekspressi, pembatasan jabatan presiden dan desentralisasi.

Menarik diperhatikan, terjadi kecenderungan menurunnya daya tarik keagamaan ketika diharapkan menjadi tenaga magnet untuk menarik massa.

34 Sukamto, Dinamika Politik Islam di Indonesia; dari Masa Orde Baru Sampai Masa Reformasi (Bandung: Enlightenment, 2008), hal. 10. 
Parpol yang selama ini selalu dikaitkan dengan semangat dan ciri keagamaan, justeru mengalami penurunan. Sementara itu, parpol yang dianggap nasionalis atau sekuler justeru berusaha mengakomodasi dan mempromosikan nilainilai dan simbol keagamaan. ${ }^{35}$ Situasi ini mengingatkan kita pada slogan dan pemikiran yang pernah dilontarkan almarhum Nurcholish Madjid; Islam Yes, Partai Islam No. Tak heran jika parpol yang selama ini dianggap ekslusif sebagai pertain keagamaan mulai membuka diri untuk menerima kader yang berbeda keyakinan agamanya.

Variabel lain yang membuat panggung politik kian tampak heboh dan sulit diprediksi adalah munculnya kekuatan opini lewat lembaga survey dan media sosial. Penggunaan televisi untuk mempersuasi massa masih tetap dianggap paling efektif sehingga muncul istilah telepolitics meskipun komunikasinya satu arah (one-way traffic communication). Iklan politik telah menjadi bagian dari industri kapitalis yang bergerak dalam bidang media sosial. Hal ini sangat berkaitan dengan lembaga survey politik yang berusaha membentuk opini massa untuk memilih partai dan tokoh tertentu, sekalipun dengan mengorbankan otentisitas parpol dan tokohnya. ${ }^{36}$ Dengan kata lain, di samping adanya parpol, media massa tertentu telah mengalami metamorphosis menjadi aktor dan kekuatan politik yang efektif untuk membangun wacana dan opini. Obyektivitas pemberitaan semakin tergeser.

Dalam kontek ini, Syafii Maarif, optimis Islam akan mampu memberi corak pertumbuhan dan perkembangan masyarakat yang berwawasan moral. Asalkan Islam dipahami secara benar dan realistis, tidak diragukan lagi akan berpotensi dan berpeluang besar untuk ditawarkan sebagai pilar pilar peradaban alternatif di masa depan. Sumbangsih solusi Islam terhadap masalah masalah kemanusiaan yang semakin lama semakin komplek ini, baru punya makna historis bila umat Islam sendiri dapat tampil sebagai umat yang beriman. ${ }^{37}$

Menyikapi tantangan tersebut, hal paling mendasar adalah bahwa umat Islam tidak boleh terpecah belah oleh dua kutub pemikiran: antara ilmu agama

35 Nurcholish Madjid, Cita-Cita Politik Islam Era Reformasi,(Jakarta: Paramadina, 1999), hal. 110.

36 Bahtiar Efendi. Repolitisasi Islam; Pernahkah Islam Berhenti Berpolitik?, (Bandung: Mizan, 2002).

37 Ahmad Syafi'i Maarif, Islam dalam Bingkai Keindonesian dan Kemanusian Sebuah Refleksi Sejarah, (Bandung: Mizan, 2009), hal. 123. 
dan ilmu sekuler. Dengan bekal perpaduan spritual dan intelektual, maka posisi umat Islam yang semula berada di buritan, dimasa mendatang diharapkan menjadi lokomotif dalam membangun masyarakat bermoral yang diback up kemantapan ontologi. Kalau mau menelusuri sejauhmana pengaruh Islam terhadap perpolitikan di Indonesia, akar sejarahnya boleh dikata cukup panjang. Wawasan moral tentang kekuasaan itulah yang dimaksud aspirasi Islam. Bagi Islam, apa yang bernama kekuasaan politik haruslah dijadikan "kendaraan" penting untuk mencapai tujuan Islam seperti: penegakkan keadilan, kemerdekaan, humanisme egaliter, yang berlandaskan nilai nilai tauhid. Bagaimanapun harus diakui bahwa Islam merupakan faktor yang teramat penting bagi partaipartai yang berasaskan Islam, seperti PPP dan PKS. Tanpa Islam, Partai Politik Islam akan eksis di bumi nusantara ini.

Dalam kondisi bangsa yang sangat memprihatinkan sekarang, sudah waktunya bagi kita semua untuk berpikir jernih, serius, tidak terombang ambing oleh pernyataan pernyataan politik yang a historis. Karena, semua itu penuh racun yang menghancurkan. Golongan santri tidak boleh lagi bermain di wilayah pinggir sejarah, turut menari menurut irama genderang yang ditabuh pihak lain. Oleh sebab itu, kita perlu menyiapkan para pemain yang handal, berakhlak mulia, profesional, dan punya integritas pribadi yang tangguh dan prima.

\section{Penutup}

Politik Islam dihadapkan pada beberapa pilihan strategis yang masing-masing mengandung konsekuensi dalam dirinya. Pertama, strategi akomodatif justifikatif terhadap kekuasaan negara yang sering tidak mencerminkan idealisme Islam dengan konsekuensi menerima penghujatan dari kalangan "garis keras" umat Islam. Kedua, strategi isolatif-oposisional, yaitu menolak dan memisahkan diri dari kekuasaan negara untuk membangun kekuatn sendiri, dengan konsekuensi kehilangan faktor pendukungnya, yaitu kekuatan negara itu sendiri, yang kemudian dikuasai dan dimanfaatkan oleh pihak lain. Ketiga, strategi integratifkritis, yaitu mengintegrasikan diri ke dalam kekuasaan negara, tetapi tetap kritis terhadap penyelewengan kekuasaan dalam suatu perjuangan dari dalam. Namun, strategi ini sering berhadapan dengan hegemoni negara itu sendiri, sehingga efektifitas perjuangannya dipertanyakan. 


\section{DAFTAR PUSTAKA}

A.Ubaedillah dan Abdul Rozak, (Penyunting), Demokrasi, Hak Asasi Manusia dan Masyarakat Madani, (Jakarta: ICCE (Indonesian Center for Civic Education, 2006).

Abd. Razak Ahmad Sanhuri, Usūl al Hukmi fì al Islām, (Mesir: Mahrajan al Qirā'ah lil Jami', Maktabah al Usrah, 2003).

Abdul Mukti Tabrani, "Politik Kiai dan Kiai Politik", Jawa Pos, 09 Januari 2004.

Abī al Hasan 'Alī bin Muhammad bin Habīb al Bahrī al Baghdādī al Māwardī, Al Ahkām al Sulțāniyyah wa al Walāyāt al Dìniyyah, (Beirut: Dār al Kutub al 'Ilmiyah, $450 \mathrm{H}$ )

Ahmad Syafi'iMaarif, Islam dalamBingkaiKeindonesiandanKemanusianSebuahRefleksiSejarah, (Bandung: Mizan, 2009)

Ali Abd. al Raziq, Al Islām wa Usūl al Hukmi: Bahth fĩ al Khilāfah wa al Hukumah fì al Islām,(Mesir:Dār al Hilal, 1925)

Antony Black, PemikiranPolitik Islam Dari MasaNabiHinggaMasaKini, (Terj:Abdullah Ali \& Mariana Ariestyawati, (Jakarta: PT SerambillmuSemesta, 2006)

AzyumardiAzra,IslamSubstantif Agar UmatTidakJadiBuih, (Bandung :Mizan, 2000)

Bassam Tibi, Islam Kebudayaandan PerubahanSosial, (Terj:Misbah Zulfa Ellizabet dan Zainul Abbas), (Yogyakarta: Tiara Wacana, 1999)

Efendi Bahtiar. Repolitisasi Islam; Pernahkah Islam Berhenti Berpolitik?, (Bandung: Mizan, 2002).

Ibn Mandhur, Lisān al Arab, Vol, 6 (Bairut: Dār Ihya al Turath al Araby, 1999). IbnQayyim, Atțurūq,

Khalid Ahmad al Shantut," al Tarbiyah as Siyāsah fí al Mujtama' al Muslim, (Beirut: Dār al Bayāriq, 2000)

Khalid Ahmad al Shantut," al Tarbiyah as Siyāsah fi al Mujtama' al Muslim, (Beirut: Dār al Bayāriq, 2000)

Leonard Binder, Islam Liberal Kritik terhadap Ideologi-Ideologi Pembangunan, (Terj: Imam Muttaqin), (Yogyakarta: Pustaka Pelajar, 2001)

Masykuri Abdillah, Demokrasi di Persimpangan Makna; Respon Intelektual Muslim Indonesia terhadap Konsep Demokrasi (1966-1993), (Yogyakarta: Tiara Wacana, 1999). 
Masykuri Abdillah, Menuju Demokrasi Yang Religius, dalam http:/ /www.nu.or. id/page. php?lang=id\&news_view_id=1253 (20 Februari 2004)

Max Weber, "The Sociology of Religion", (Boston: Beacon Press,1963).

Muhammad Saltut, Al Islām 'Aqidah wa Shari'ah, (Mesir: Dār al Qalam, 1966)

Muhmmmad Imarah, Al-Islām Waal-Siyāsah al-RaddAla Shibhati al-Alamaniyyinā, (Mesir: Dār al-Tauzi' wa al-Nashr al-Islāmiyah, 2007).

Munawir Sjadzali, Islam dan Tata Negara; Ajaran, Sejarah dan Pemikiran, (Jakarta: Universitas Indonesia Press, 1993)

NurcholishMadjid,Cita-CitaPolitik Islam Era Reformasi,(Jakarta: Paramadina, 1999)

NurcholishMadjid, "Islam danPolitik, SuatuTinjauanatasPrinsip-PrinsipHukumdanKeadilan", JurnalPemikiran Islam Paramadina, No (Juli, 1998)

R. HrairDekmejian, "Islamic Revival Catalysts, Categories, and Consequences", dalamThe Politic of Islamic Revivalism, Diversity and Unity, edShirren T. Hunter (Washington, D.C: Indiana University Press, 1988)

R. HrairDekmejian, "Islamic Revival Catalysts, Categories, and Consequences”, dalamThe Politic of Islamic Revivalism, Diversity and Unity, edShirren T. Hunter (Washington, D.C: Indiana University Press, 1988)

Sukamto, Dinamika Politik Islam di Indonesia ; dari Masa Orde Baru Sampai Masa Reformasi (Bandung: Enlightenment, 2008)

Sukron Kamil, Peta Pemikiran Politik Islam Modern dan Kontemporer, Jurnal Universitas Paramadina, Vol.3 No.1 (September 2003)

Sukron Kamil, Peta Pemikiran Politik Islam Modern dan Kontemporer, Jurnal Universitas Paramadina, Vol.3 No.1 (September 2003)

Syek Muhammad Ridha al Musaffar, Akidah Syiah Imāmiyah, (Terj;Muhammad H. Acango), (Jakarta: Abudzarr Press, t.t)

Zainuddin Maliki, Agama Priyayi Makna Agama di Tangan Elit Penguasa, (Yogyakarta: Pustaka Marwa, 2004) 